OPEN ACCESS

Edited by:

Giovanni Martinelli,

National Institute of Geophysics and

Volcanology, Italy

Reviewed by:

Jiwei Li,

Institute of Deep-Sea Science and Engineering (CAS), China

Venkatramanan Senapathi,

Ton Duc Thang University, Vietnam

*Correspondence:

Zhiguang Song

zgsong_ocean@163.com

Specialty section:

This article was submitted to

Geochemistry,

a section of the journal

Frontiers in Earth Science

Received: 31 December 2020

Accepted: 03 January 2022

Published: 01 February 2022

Citation:

Xia J, Han Y, Tan J, Abarike GA and Song $Z$ (2022) The Characteristics of

Organic Carbon in the Offshore Sediments Surrounding the Leizhou

Peninsula, China.

Front. Earth Sci. 10:648337.

doi: $10.3389 /$ feart.2022.648337

\section{The Characteristics of Organic Carbon in the Offshore Sediments Surrounding the Leizhou Peninsula, China}

\author{
Jia Xia ${ }^{1,2}$, Yongqiang Han ${ }^{1}$, Jingqian Tan ${ }^{1}$, Grace Awinmalsim Abarike ${ }^{1}$ and Zhiguang Song ${ }^{1 *}$ \\ ${ }^{1}$ Faculty of Chemistry and Environmental Science, Guangdong Ocean University, Zhanjiang, China, ${ }^{2}$ Southern Marine Science \\ and Engineering Guangdong Laboratory (Zhanjiang), Zhanjiang, China
}

A total of 43 seafloor surface sediment samples collected from the offshore region surrounding the Leizhou Peninsula were analyzed in terms of the total organic carbon content (TOC), total nitrogen (TN), organic carbon isotope $\left(\delta^{13} \mathrm{C}_{\mathrm{org}}\right)$ and sediment grain size. Our results showed that the organic carbon content in the samples ranged from 0.12 to $0.79 \%$, with an average of $0.42 \%$ which was lower compared with other offshore regions of China, whereas the $\delta^{13} \mathrm{C}_{\text {org }}$ was in the range of $-22.47 \%$ o to $-19.18 \%$. The total nitrogen content ranged from 0.011 to $0.100 \%$ which was also low. The combination of $\delta^{13} \mathrm{C}_{\text {org }}$ and TOC/TN ratio (5.1-14.3) suggested that the organic matter is dominant by marine authigenic source input, as marine sourced organic matter accounts for $71 \%, 82 \%$, and $75 \%$ in the sediments from the offshore areas of the east side, west side and the south (Qiongzhou Strait) of the Leizhou Peninsula, respectively. The weak/poor correlations between the organic carbon and clay, silt content, the $\mathrm{pH}$ and Eh value suggested that organic matter abundance and distribution were influenced by the source input of organic matter, the seafloor sediments' redox status, and seawater's hydrodynamic condition.

Keywords: seafloor sediments, TOC, organic carbon isotope, TN, offshore of the Leizhou Peninsula

\section{INTRODUCTION}

The ocean is the most important carbon pool on the earth's surface and a vital system of the global carbon cycle (Gao et al., 2008; Larowe et al., 2020; Yu et al., 2021). The total carbon storage in the ocean is about 50 times that of carbon in the atmosphere (Falkowski et al., 2000), and plays an important role in regulating atmospheric $\mathrm{CO}_{2}$ concentration. $\mathrm{Al}$ thought accounting for just $7.6 \%$ of the total global ocean area, the marginal sea plays a major role in the global carbon cycle (Bianchi et al., 2018), as the coastal zone and shelf marginal sea sediments account to more than $96 \%$ of yearly buried carbon of the whole ocean (Burdige, 2005; Burdige, 2007). While the buried marine organic matter $(\mathrm{OM})$ also plays a key role in controlling atmospheric carbon dioxide and oxygen concentrations in addition to the fossil fuel formation over the past 500 million years (Berner et al., 2003). Therefore, the study of the organic carbon abundance and its distribution in the offshore seafloor sediments is of scientific significance for understanding and predicting future marine ecological environments and changes (Borges et al., 2005).

Many studies have been carried out on the organic matter abundance and distribution of the seafloor surface sediments in China's offshore areas, such as the Bohai sea (Gao et al., 2016; Wang et al., 2020; Yang et al., 2021), the Yellow Sea (Xiong et al., 2013; Zhang et al., 2014; Liu et al., 2020), 
the Yangtze River Estuary (Kang et al., 2014; Fan et al., 2017; Zhang et al., 2020), the East China Sea (Guo et al., 2001), and the Pearl River Estuary in the northern South China Sea (Lian et al., 2019; Yuan et al., 2019; Liu et al., 2018). Guangzhou Marine Geological Survey had conducted a comprehensive research project of "Holocene Environmental Evolution and Anthropogenic impact of the Beibu Gulf, South China" since 2009. In this project, two joint expeditions with the Leibniz Institute for Baltic Sea Research of Germany were carried out in 2009 and 2011, respectively. The objectives of this project were focused on the acquisition of new data such as ocean graphic data, bathymetric measurements, high-resolution seismic data on the structure of Quaternary sediments (Cui et al., 2017). For the first time, a map of Holocene stratigraphic thickness distribution in the eastern Beibu Gulf has been created, with two depositional centers and six provenance areas delineated (Cui et al., 2017). After establishing a long-term topography evolution model for the Beibu Gulf and inverting paleotopographic changes since $6,000 \mathrm{BP}$, the sedimentary environment evolution history of Beibu Gulf was investigated (Cui et al., 2017). The outcome of this project and other previous studies had also provided some new information on the organic carbon contents, some specific molecular compounds and heavy metal pollutants (Zhang et al., 2011; Zhang et al., 2012; Chen et al., 2014; Cui et al., 2015; Jin et al., 2019; Liu and Chao, 2019). However, the expedition and sampling area of this project-were mainly in the far offshore and relatively deep-water areas, and there is a lack of investigation on sedimentary organic matter in the near coastal region surrounding the Leizhou Peninsula.

Being the important low latitude marine continental transition zone, the offshore surrounding the Leizhou Peninsula is a typical region which influenced by the East Asian monsoon. The coastal area of the Leizhou Peninsula is also the most important region of the mangrove ecosystem in China and it may have significant effects on the carbon pool of marine sediments in the offshore region (Yang et al., 2012). Furthermore, there is intense aquaculture in the shallow coastal water and bay region along the Leizhou Peninsula offshore. These offshore aquaculture industries would consume a large amounts of fish food. Therefore, the metabolic activities of the cultured organisms will impact the abundance of organic matter in the offshore sediments. In general, the abundance and preservation of organic matter in the seafloor surface sediments are controlled by the primary productivity and sedimentary environment, and influenced by human activities in this region. In this study, we aimed to investigate the total organic carbon content in the seafloor sediments and its distribution, origin and controlling factors in the offshore region surrounding the Leizhou Peninsula and study the carbon preservation in the nearshore seafloor sediments and their environmental significance.

\section{SAMPLES AND EXPERIMENTS}

\subsection{Geological and Geographical Background of the Study Area}

Being the third-largest peninsula in China, the Leizhou Peninsulalocates at the southern tip of the Chinese mainland
(Figure 1). The peninsula is about $140 \mathrm{~km}$ long from north to south and $60-70 \mathrm{~km}$ wide from east to west which covers more than $13,000 \mathrm{~km}^{2}$, and is surrounded by the Zhanjiang Bay (formerly known as Guangzhou Bay), the Qiongzhou Strait and the Beibu Gulf with a coastline about $1,180 \mathrm{~km}$. A few small rivers enter the surrounding sea area including the Nandu River, the Xixi River, the Yingli River, the Tongming River, and the Jianjiang River. Although these rivers have small flows, their influence on organic carbon input and preservation in the seafloor sediments could not be ignored. They could carry terrestrial organic matter into the offshore area. The coastline of the peninsula is quite twisty, and there are many harbors and islands. The great variation in the geomorphologic condition of the coastline could also cause significant changes in the sedimentary condition of the offshore region. The eastern part of the Leizhou Peninsula is a kind of coast consisting of platform submerged bay, the southern part is a kind of volcanic platform coast, and the west is the coast consisting of sea terrace and platform submerged bay. The type of tide and its impact on the east and west coastlines of the peninsula are significantly different. An irregular semi-diurnal tide affects the east coast and the west coast is affected by a regular diurnal tide. The tidal conditions in the Qiongzhou Strait are more complicated, as the flood tide runs from the west to the east and the ebb tide runs from the east to the west. The eastward currents flow fast than the westward currents (Liu et al., 2015). From previous studies based on the trajectory of the drifting bottle in the offshore region of the western Guangdong and the fixed-point observation of the currents, the coastal currents in western Guangdong generally flow to the southwest all the year round, and goes south along the east coast of the Leizhou Peninsula (Yang et al., 2003). In addition, the direction of the waves in the Beibu Gulf area depends on the wind direction, and the waves are mostly northeast direction during winter and the southwest direction during summer (EBCBS, 1993). Therefore, the sedimentary environments in the offshore region of the Leizhou Peninsula are complicated. The marine survey and sampling region are in the offshore area of the Leizhou Peninsula, within a geographical range between $20^{\circ} 15^{\prime} \sim 21^{\circ} 30^{\prime} \mathrm{N}$ north latitude and $109^{\circ} 30^{\prime} \sim 111^{\circ} 45^{\prime} \mathrm{E}$ east longitude (Figure 1).

\subsection{Sample Collection and Analytical Methods}

The seafloor sediment samples were collected using a gravity box sampler during the Guangdong Ocean University's comprehensive marine environmental and ecological survey surrounding the Leizhou Peninsula in autumn 2017 (September $29 \sim$ October 7). A total of 43 seafloor surface sediment samples were obtained from 57 pre-determined sampling sites as shown in Figure 1. The water depth of the sampling sites ranges from 8 to $50 \mathrm{~m}$ and is listed in Table 1. It should be pointed out that about 13 locations among the 57 sampling sites were sandy seabed where the sandy samples were not collected. The on-site measurement of the samples' redox potential (Eh) and $\mathrm{pH}$ values were immediately carried out when the sediments were taken to the rear deck of the vessel. However, these on-site measurements were only performed on the sampling sites where the sampled sediment column was in 


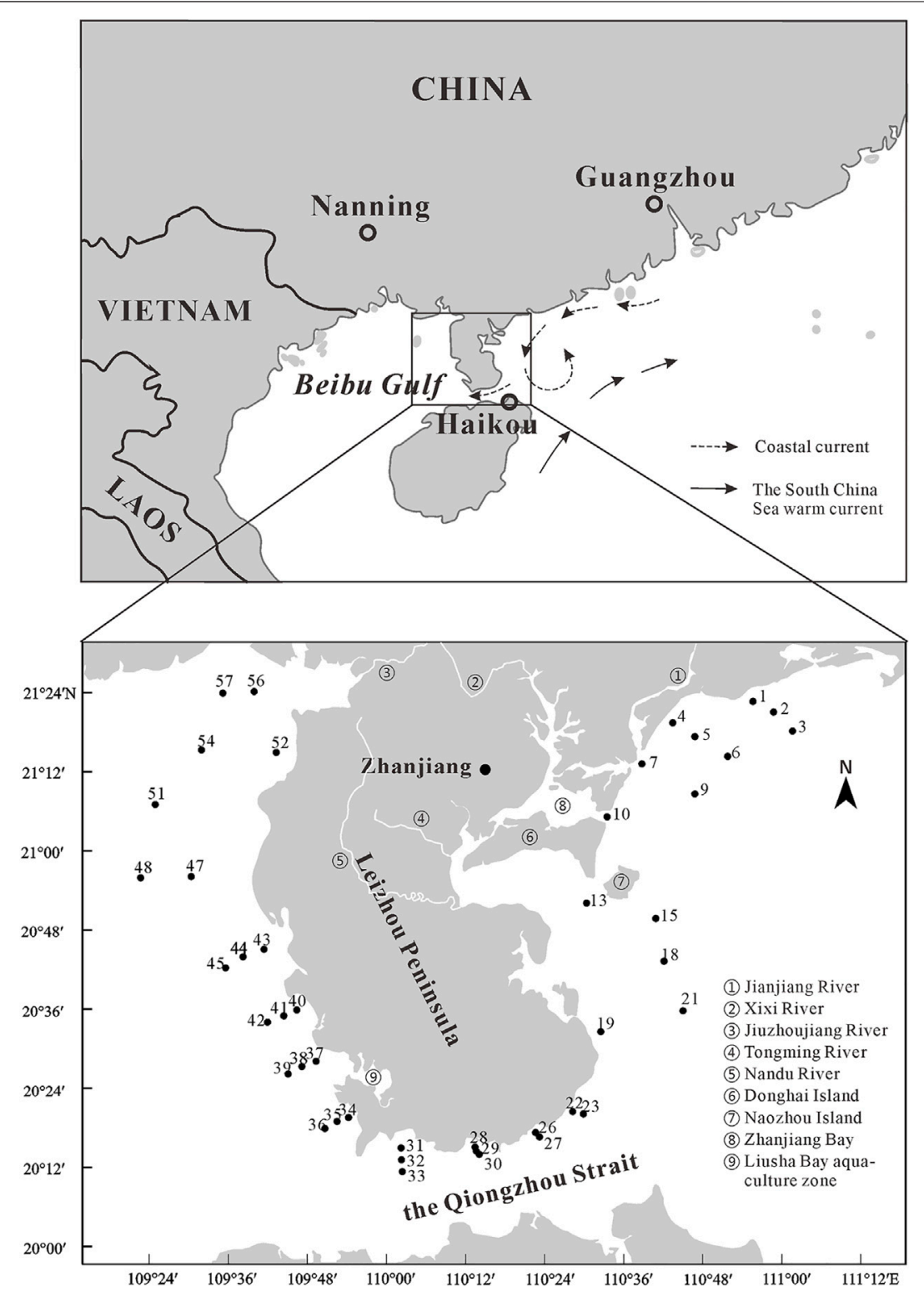

FIGURE 1 | Map of the near offshore region and sampling locations surrounding the Leizhou Peninsula.

good shape and not severely disturbed by the sampling process from the seafloor. A DZB-718L portable multi-parameter analyzer coupled with an oxidation-reduction potential (ORP) platinum electrode and $\mathrm{pH}$ glass electrode (with an accuracy of $0.1 \mathrm{mV}$ and 0.1 , respectively) was used for measuring $\mathrm{Eh}$ and $\mathrm{pH}$ values. The electrodes were rinsed with ultra-pure water before use, then $\mathrm{Eh}$ and $\mathrm{pH}$ electrodes were calibrated with ORP standard solution and standard buffer solutions $(\mathrm{pH}=4.01,7.00,10.01)$, respectively. The calibrations satisfy the requirement that the values of three consecutive measurements were the same, and the values were rapidly stable within 1 min of each measurement. The sediment samples were collected on-site by taking the undisturbed $0-10 \mathrm{~cm}$ thickness of top layer sediments from the sediment block taken by the box sampler and packed into the PE (TWIRL"EM) sterile sample bag. After removing air from the sample bag, the sealed sample bags were frozen and stored in the refrigerator. The samples were carried back to the laboratory and freeze-dried for further treatment and following experimental analysis.

\subsection{Sediment Grain Size Analysis}

The particle size analysis was performed on a Malvern Mastersizer 2000 laser particle size analyzer. Before measuring particle size, a small amount of the original wet sediments was treated with $30 \% \mathrm{H}_{2} \mathrm{O}_{2}$ solution to remove organic matter. Precisely $1 \mathrm{~mol} / \mathrm{L}$ hydrochloric acid was added to remove carbonate, followed by washing with ultra-pure water. The final sediment residue was added with sodium hexametaphosphate as a dispersant with full shaking and then ready for particle size analysis. Instrumental measurement's size 
TABLE 1 | TOC content and related measurement data in the offshore samples of the Leizhou Peninsula.

\begin{tabular}{|c|c|c|c|c|c|c|c|c|c|c|c|c|}
\hline $\begin{array}{l}\text { Sample } \\
\text { site }\end{array}$ & $\begin{array}{c}\text { Water } \\
\text { depth } \\
\text { (m) }\end{array}$ & $\begin{array}{l}\text { Sediment } \\
\text { types }\end{array}$ & $\begin{array}{l}\text { TOC } \\
(\%)\end{array}$ & $\begin{array}{l}\text { TN } \\
(\%)\end{array}$ & $\begin{array}{c}\text { TOC/ } \\
\text { TN }\end{array}$ & $\begin{array}{c}\delta^{13} C_{\text {org }} \\
(\% \circ)\end{array}$ & $\mathrm{pH}$ & $\begin{array}{c}\text { Eh } \\
(\mathrm{mV})\end{array}$ & $\begin{array}{l}\text { Clay } \\
(\%)\end{array}$ & $\begin{array}{l}\text { Silt } \\
(\%)\end{array}$ & $\begin{array}{c}\text { Sand } \\
(\%)\end{array}$ & $\begin{array}{c}\text { Median } \\
\text { particle } \\
\text { size } \\
\text { (Ф) }\end{array}$ \\
\hline P1 & 12.0 & Mud & 0.28 & 0.055 & 5.1 & -20.95 & 7.63 & -123.6 & 23.9 & 55.9 & 20.3 & 6.43 \\
\hline P2 & 10.0 & Mud & 0.30 & 0.058 & 5.2 & -21.50 & 7.59 & -183.8 & 21.8 & 59.9 & 18.4 & 6.48 \\
\hline P3 & 15.0 & Mud & 0.59 & 0.078 & 7.6 & -21.27 & 7.63 & -145.3 & 26.3 & 55.6 & 18.1 & 6.64 \\
\hline P4 & 10.0 & Mud & 0.35 & 0.042 & 8.3 & -21.02 & 7.55 & -101.3 & 25.4 & 62.5 & 12.2 & 6.42 \\
\hline P5 & 14.0 & Mud & 0.31 & 0.039 & 7.9 & -20.80 & 7.89 & -172.5 & 28.7 & 57.8 & 13.6 & 6.86 \\
\hline P6 & 17.0 & Mud & 0.51 & 0.067 & 7.6 & -21.15 & 7.73 & -146.9 & 24.5 & 63.9 & 11.6 & 6.55 \\
\hline P7 & 11.0 & Mud & 0.55 & 0.054 & 10.2 & -21.54 & 7.51 & -168.0 & 30.0 & 65.6 & 4.4 & 6.91 \\
\hline P9 & 17.0 & Mud & 0.43 & 0.050 & 8.6 & -21.27 & 7.78 & -109.3 & 29.4 & 62.1 & 8.5 & 6.91 \\
\hline P10 & 13.0 & Silty & 0.36 & 0.036 & 10.0 & -21.66 & 7.76 & -121.7 & 31.0 & 64.1 & 4.9 & 6.99 \\
\hline P13 & 25.0 & Sandy & 0.19 & 0.021 & 9.0 & -19.95 & 7.74 & -128.5 & 31.5 & 49.1 & 19.4 & 6.88 \\
\hline P15 & 18.0 & Mud & 0.52 & 0.059 & 8.8 & -21.52 & - & -133.8 & 29.2 & 63.5 & 7.3 & 6.90 \\
\hline P18 & 16.1 & Mud & 0.34 & 0.028 & 12.1 & -20.13 & - & -71.0 & 32.1 & 56.2 & 11.7 & 6.91 \\
\hline P19 & 8.0 & Mud & 0.34 & 0.045 & 7.6 & -20.16 & 7.71 & -101.7 & 20.8 & 48.3 & 30.9 & 4.90 \\
\hline P21 & 16.5 & Silty & 0.12 & 0.011 & 10.9 & -21.16 & - & 10.5 & 13.6 & 26.9 & 59.5 & 3.55 \\
\hline P22 & 15.0 & Sandy mud & 0.36 & 0.038 & 9.5 & -22.47 & 7.71 & -71.2 & 19.1 & 66.2 & 14.7 & 5.75 \\
\hline P23 & 19.0 & Sandy mud & 0.33 & 0.040 & 8.3 & -20.38 & 7.73 & 9.5 & 27.4 & 62.7 & 9.9 & 6.79 \\
\hline P26 & 20.0 & Mud & 0.45 & 0.046 & 9.8 & -20.78 & - & -51.2 & 20.7 & 50.4 & 28.9 & 5.23 \\
\hline P27 & 20.0 & Mud & 0.59 & 0.070 & 8.4 & -21.24 & 7.5 & -129.5 & 30.1 & 59.9 & 10.0 & 6.90 \\
\hline P28 & 11.0 & Mud & 0.49 & 0.050 & 9.8 & -21.05 & - & -146.7 & 22.5 & 52.7 & 24.8 & 5.71 \\
\hline P29 & 10.8 & Mud & 0.51 & 0.058 & 8.8 & -20.95 & 7.56 & -64.7 & 29.6 & 62.3 & 8.1 & 6.95 \\
\hline P30 & 43.0 & Mud & 0.29 & 0.036 & 8.1 & -20.03 & 7.25 & -137.0 & 18.5 & 53.4 & 28.1 & 5.45 \\
\hline P31 & 10.0 & Mud & 0.33 & 0.037 & 8.9 & -20.32 & 7.45 & -122.3 & 25.5 & 43.4 & 31.1 & 6.17 \\
\hline P32 & 23.0 & Mud & 0.50 & 0.041 & 12.2 & -20.90 & 7.7 & -52.0 & 22.7 & 62.7 & 14.6 & 5.91 \\
\hline P33 & 50.0 & Gritty & 0.34 & 0.036 & 9.5 & -20.47 & - & -132.5 & 21.0 & 55.7 & 23.4 & 5.30 \\
\hline P34 & 12.0 & Mud & 0.43 & 0.044 & 9.8 & -19.39 & 7.63 & -176.0 & 31.1 & 47.2 & 21.7 & 7.00 \\
\hline P35 & 14.0 & Mud & 0.71 & 0.084 & 8.45 & -20.54 & 7.53 & -125.0 & 30.0 & 66.6 & 3.4 & 6.94 \\
\hline P36 & 19.0 & Mud & 0.52 & 0.063 & 8.3 & -20.81 & 7.67 & -85.3 & 30.2 & 61.9 & 7.9 & 6.93 \\
\hline P37 & 11.5 & Mud & 0.79 & 0.100 & 7.9 & -20.65 & 7.4 & -121.4 & 36.8 & 61.6 & 1.6 & 7.43 \\
\hline P38 & 17.0 & Mud & 0.57 & 0.064 & 8.9 & -20.57 & 7.62 & -255.1 & 32.4 & 58.2 & 9.4 & 7.07 \\
\hline P39 & 19.0 & Mud & 0.70 & 0.070 & 10.0 & -20.66 & 7.75 & -130.9 & 32.9 & 56.4 & 10.8 & 7.04 \\
\hline P40 & 9.0 & Mud & 0.75 & 0.093 & 8.1 & -20.61 & 7.46 & -121.5 & 34.2 & 60.1 & 5.8 & 7.24 \\
\hline P41 & 11.0 & Mud & 0.63 & 0.068 & 9.3 & -20.38 & 7.57 & -109.5 & 36.1 & 53.2 & 10.7 & 7.31 \\
\hline P42 & 16.0 & Mud & 0.50 & 0.062 & 8.1 & -20.37 & 7.66 & -100.0 & 31.9 & 58.6 & 9.5 & 7.01 \\
\hline P43 & 10.0 & Mud & 0.23 & 0.016 & 14.4 & -19.45 & 7.66 & -120.3 & 39.6 & 47.1 & 13.3 & 7.48 \\
\hline P44 & 12.0 & Mud & 0.54 & 0.062 & 8.7 & -19.18 & 7.48 & -83.6 & 37.6 & 54.9 & 7.5 & 7.39 \\
\hline P45 & 17.0 & Mud & 0.55 & 0.058 & 9.5 & -19.70 & - & -107.8 & 30.7 & 59.5 & 9.8 & 7.13 \\
\hline P47 & 17.0 & Sand & 0.20 & 0.017 & 11.8 & -20.14 & 7.68 & -93.4 & 29.0 & 51.7 & 19.3 & 7.09 \\
\hline P48 & 17.0 & Mud & 0.26 & 0.024 & 10.8 & -19.73 & 7.84 & -190.4 & 24.0 & 34.2 & 41.9 & 6.24 \\
\hline P51 & 19.0 & Mud & 0.48 & 0.062 & 7.7 & -20.00 & 7.39 & -181.2 & 36.7 & 54.5 & 8.8 & 7.37 \\
\hline P52 & 8.5 & Mud & 0.23 & 0.026 & 8.8 & -19.96 & 7.61 & -83.1 & 33.5 & 34.4 & 32.1 & 6.82 \\
\hline P54 & 13.0 & Sand & 0.19 & 0.021 & 9.0 & -20.06 & 7.46 & -76.7 & 21.0 & 19.8 & 59.2 & 3.38 \\
\hline P56 & 10.0 & $\begin{array}{l}\text { Coarse } \\
\text { sand }\end{array}$ & 0.13 & 0.011 & 11.8 & -21.37 & 7.55 & -97.5 & 9.4 & 14.6 & 76.1 & 1.57 \\
\hline P57 & 9.0 & Mud & 0.53 & 0.054 & 9.8 & -20.52 & 7.5 & -151.1 & 36.0 & 50.7 & 13.3 & 7.18 \\
\hline
\end{tabular}

range was $0.2 \sim 1,000 \mu \mathrm{m}$ with a granularity resolution of less than $0.01 \Phi$. Particle size distributions were accounted as an incremental percentage as particles smaller than $4 \mu \mathrm{m}$ were considered as clays, $4 \sim 63 \mu \mathrm{m}$ as silts and particle size larger than $63 \mu \mathrm{m}$ as sand (Folk et al., 1970). The relative error of repeated measurements was $<1 \%$.

\subsection{TOC, TN and Organic Carbon Isotope Analysis}

The freeze-dried sediments were initially ground to 100 mesh powder for instrumental analysis or further treatments. For TOC analysis, the powder samples were treated with $10 \%$ hydrochloric acid to remove the inorganic carbon (Schubert and Calvert, 2001; Liu et al., 2015). The dry powder sediments were initially soaked with $10 \%$ hydrochloric acid under heating of $60^{\circ} \mathrm{C}$ for $24 \mathrm{~h}$, and then using a centrifuge to remove the supernatant. They were treated with $10 \%$ hydrochloric acid again for $4 \mathrm{~h}$ to remove the residue carbonate. The solid residues were washed with ultrapure water to neutrality and dried at a temperature of $60^{\circ} \mathrm{C}$. And then take about $20 \sim 30 \mathrm{mg}$ of the treated residue powder sample for instrumental analysis of TOC. According to the weight difference before and after pickling, the final content of total organic carbon in the sample was obtained by adjusting measured data to the sample weight before acid treatment. While the total nitrogen (TN) was measured using the initial powder samples 


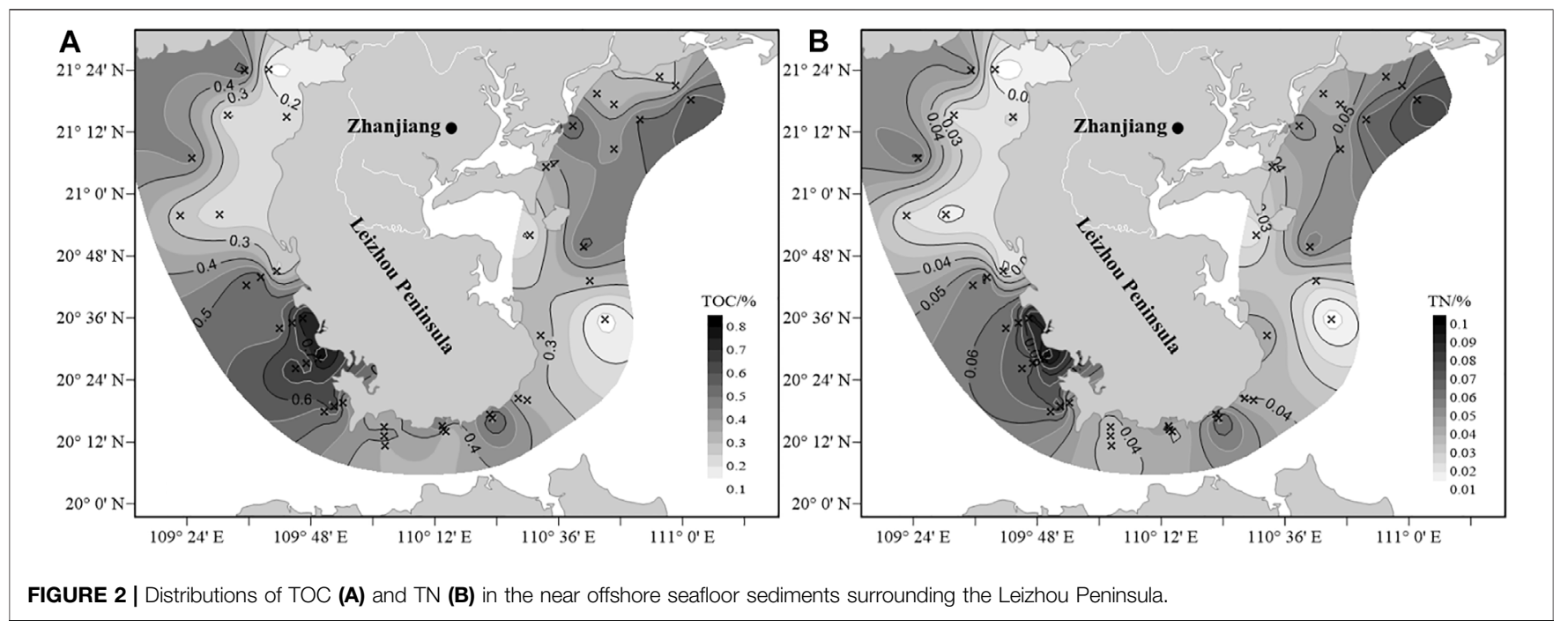

without any further treatment. Both TOC and TN measurement was performed on a German Elementar vario MACRO Organic Element Analyzer. The analysis errors of TOC and TN were $\pm 0.02 \%$ and $\pm 0.005 \%$, respectively.

The organic carbon isotopic $\left(\delta^{13} \mathrm{C}_{\mathrm{org}}\right)$ analysis was performed on the carbonate-free samples by a Sercon 20-22 isotope ratio mass spectrometer at the Marine and Environmental Monitoring Center of Guangdong Ocean University. The results were expressed in $\delta$ notation in parts per mil (\%o):

$$
\delta^{13} \mathrm{C}_{\text {org }}(\% 0)=\left(R_{\text {sample }} / R_{\text {reference }}-1\right) \times 1000
$$

where $R_{\text {sample }}$ and $R_{\text {reference }}$ are the isotopic ${ }^{13} \mathrm{C} /{ }^{12} \mathrm{C}$ ratios of the sample and reference, respectively. The carbon isotopic reference was PeeDee Belemnite (PDB). The samples were run in duplicate with an error of $\pm 0.2 \%$.

\section{RESULTS AND DISCUSSIONS \\ 3.1 The TOC, TN Contents and Their Distribution}

The TOC content of 43 seafloor surface sediment samples is in the range of $0.12-0.79 \%$, with an average of $0.42 \%$ (Table 1 ). Figure $\mathbf{2 A}$ is the isogram of TOC content of the 43 seafloor sediment samples from the Leizhou Peninsula offshore. It shows that the offshore area of the Liusha Bay is the high TOC content area, and the northwest part of the Beibu Gulf in the west of the Leizhou Peninsula and southeast offshore areas in the east of the Leizhou Peninsula are two low TOC content areas. Except for sediments with high organic carbon content in the Liusha Bay, the TOC content in these offshore sediments is generally low. The TOC contents in the samples of the Leizhou Peninsula offshore fall within the range of that from the vast far offshore region of the Beibu Gulf which is $0.02 \sim 0.95 \%$ (Cui et al., 2017). This further demonstrated that the whole Beibu Gulf area of the South China Sea is a lower TOC content region.
Table 2 shows that the TOC content of the samples in this study is generally low compared with other offshore areas, and the TOC content from the shallow bay sea area near the coastline is relatively high, such as the Liusha Bay of the Leizhou Peninsula and the western Guangdong Coasts. The difference reflects that the variations in the sedimentary environment between the restricted coastal areas with significant human impact and the open seas in the offshore coastal areas. As mentioned above, the east coastal offshore of the Leizhou Peninsula is greatly affected by irregular semi-diurnal tides. The strong currents with high oxygen content in the shallow region along the east coast of the Leizhou Peninsula resulted in an oxide sedimentary environment that is not favorable for the preservation and accumulation of organic matter in the seafloor sediments (Gao et al., 2016). The Qiongzhou Strait is constantly affected by the strong currents with high energy (Chen and Shi, 2019) and the seafloor sediments are dominated by sand, silty sand and sandy silt (Chen et al., 2014), so it is not favorable for the deposition and preserves of organic matter. On the other hand, the flow direction of the currents in the Qiongzhou Strait varies with the seasons, leading to a complex, oxides marine sedimentary environment, where sediments are frequently disturbed and result in organic-poor sediments (Ma et al., 2012; Chen and Shi, 2019). The Beibu Gulf is situated in the tropical-subtropical monsoon climate zone where the marine primary productivity is significantly high (Wu, 2008; Yao et al., 2021). However, due to the general shallow water depth and strong diurnal tide and currents influence, most areas of the seafloor are oxide condition which is not favorable for organic matter preservation, only in some restricted areas such as the Liusha Bay where the sea current flow rate is lower than $0.3 \mathrm{~m} / \mathrm{s}$ even at high tide time (Luo et al., 2013). Under this near quiescent flow condition, the water would be depleted of oxygen and favorable for the organic matter to be deposited and preserved, resulting in a relatively high TOC content in the sea floor sediments. On the other hand, according to the onsite observation of the seafloor sediments and benthic organism sampling, it was noticed that the seafloor sediments are generally lacking benthic animals, especially in the low TOC content sites. 
TABLE 2 | Comparison of the TOC and TN contents in the offshore surface sediments of China.

\begin{tabular}{llcll}
\hline Research sea area & TOC (\%) & TN (\%) & Sampling time \\
\hline Leizhou Peninsula offshore & $0.12 \sim 0.79(0.42)$ & $0.01 \sim 0.10(0.05)$ & October 2017 & Data sources \\
Bohai Sea & $0.19 \sim 0.81(0.46)$ & $0.02 \sim 0.12(0.07)$ & May 2012 & This study \\
Yellow Sea & $0.10 \sim 1.38(0.50)$ & $0.01 \sim 0.20(-)$ & October 2010 & Zang et al. (2016) \\
Yellow Sea, East China Sea & $0.05 \sim 1.64(0.88)$ & - & 2006 & Cai et al. (2014) \\
Western Taiwan Strait & $0.01 \sim 1.79(0.37)$ & $0.00 \sim 0.11(-)$ & April 2005 & Ye et al. (2011) \\
Pearl River Estuary & $0.36 \sim 1.40(0.66)$ & $0.02 \sim 0.10(0.04)$ & July 2013 & Lian et al. (2019) \\
Zhanjiang Port & $0.12 \sim 1.32(0.54)$ & - & February 2009 & Zhang et al. (2012) \\
Liusha Bay & $0.06 \sim 3.06(1.43)$ & $0.18 \sim 0.37(0.27)$ & February 2009 & July 2006
\end{tabular}

This phenomenon indicates that most areas of the Leizhou Peninsula offshore are in a status of severe desertification. Bioturbation and biodeposition of benthic organisms are some of the factors affecting the organic matter in sediments. Bioturbation destroys organic matter by prolonging its exposure to dissolved oxygen, while the biodeposition causes suspended particles in the water column to be deposited into the sediment as fecal pellets (Graf and Rosenberg, 1997). Muschenheim. (1987) has calculated that about $32.5 \mathrm{~kg}$ particles are deposited to the seafloor by biodeposition per square meter every year in Kiel Bay of the North Sea. Desertification also is more likely related to intensive fishing activities (Thompson, 1978; Chen et al., 2008; Yue et al., 2017). It has also been reported that bottom trawling and illegal electric fishing could result in massive depletion of benthic fauna in the offshore areas and inevitable desertification of seafloor (Wang and Yuan, 2008), and consequently affect the organic matter content of the seafloor sediments. Therefore, the low organic carbon content in the surrounding offshore seafloor sediments of the Leizhou Peninsula is related to a shallow oxidizing sedimentary condition and limited terrestrial organic matter input, and influenced by intensive fishing activities.

The total nitrogen content (TN) in the sediment samples of the 43 sampling sites is in the range of $0.011-0.100 \%$, with an average of $0.050 \%$ (Figure 2B; Table 1). Among these samples, the P37 site shows the highest TN content, which is consistent with its highest TOC content. However, the TN contents in these near coastal seafloor sediments are significantly lower than the TN contents in the seafloor sediments from the vast far offshore area of the Beibu Gulf obtained from 2009 to 2011 (Cui et al., 2017). The reason for this could be partly attributed to the geographical difference of sampling area and partly to the anthropogenic impact of fishing on the near coastal area. But it needs further investigation as the TOC content show agreement for these studies. Figure 2 shows that the spatial distribution of TOC content highly coincides with that of TN content in the seafloor surface sediments from the Leizhou Peninsula offshore. The spatial distribution of TOC and TN content in the sediments is consistent. Even the highest TN area is identical to that of the highest TOC region situated outside Liusha Bay of the southwest coast of the Leizhou Peninsula (Figure 2). Furthermore, the TOC and TN contents display a good positive linear correlation (Figure 3) with a coefficient of 0.8637 . The linear correlation between TOC and TN has no intercept indicating that nitrogen in

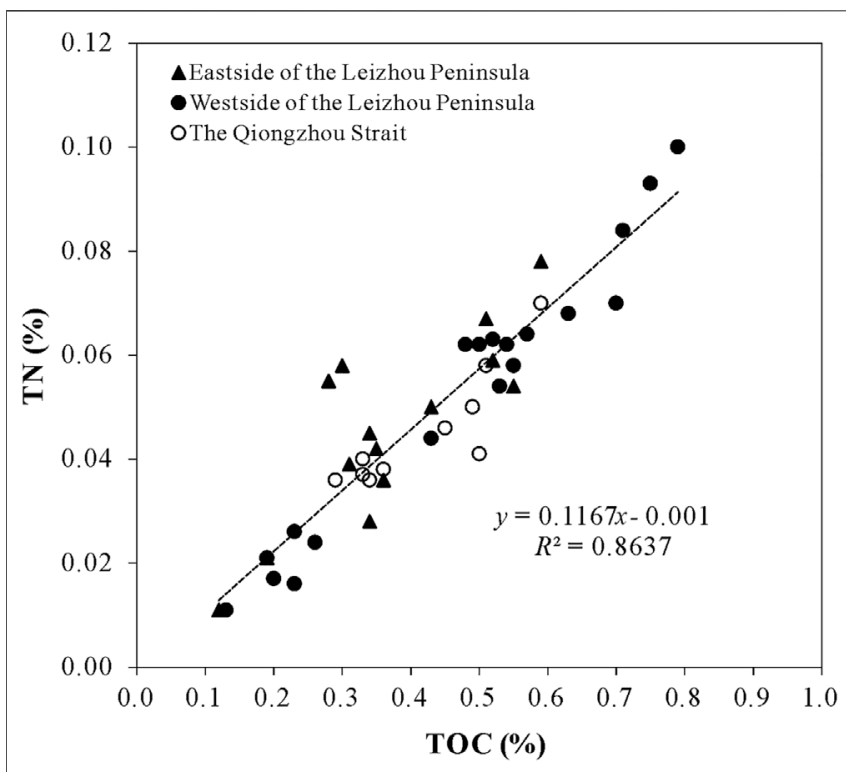

FIGURE 3 | Correlation between TOC and TN content in the near offshore seafloor sediments surrounding the Leizhou Peninsula.

the sediment mainly exists in the form of organic compounds (Goni et al., 1998; Schubert and Calvert, 2001).

\subsection{Source of the Organic Matter}

The organic matter in the seafloor sediments is mainly derived from the input of marine organisms and terrestrial organic detritus, and the proportion of these two sources varies significantly in different areas of the ocean depending on many conditions (Bianchi and Allison, 2009; Blair and Aller, 2012). The mass ratio of TOC/TN could be used to identify the input source of organic matter in marine sediments. The TOC/ $\mathrm{TN}$ less than 8 indicates the marine authigenic sourced organic matter and TOC/TN higher than 12 points the terrestrial source input, whereas the value between 8 and 12 suggests a mixed origin of marine and terrestrial input (Liu et al., 1998; Goslin et al., 2017). The TOC/TN of the samples from the Leizhou Peninsula offshore ranged from 5.1 to 14.3 , with an average of 9.1. The results indicate that most of the sedimentary organic matter in the study area has mixed input of marine and terrestrial sources, including three sediment samples with a TOC/TN ratio $>12$ 


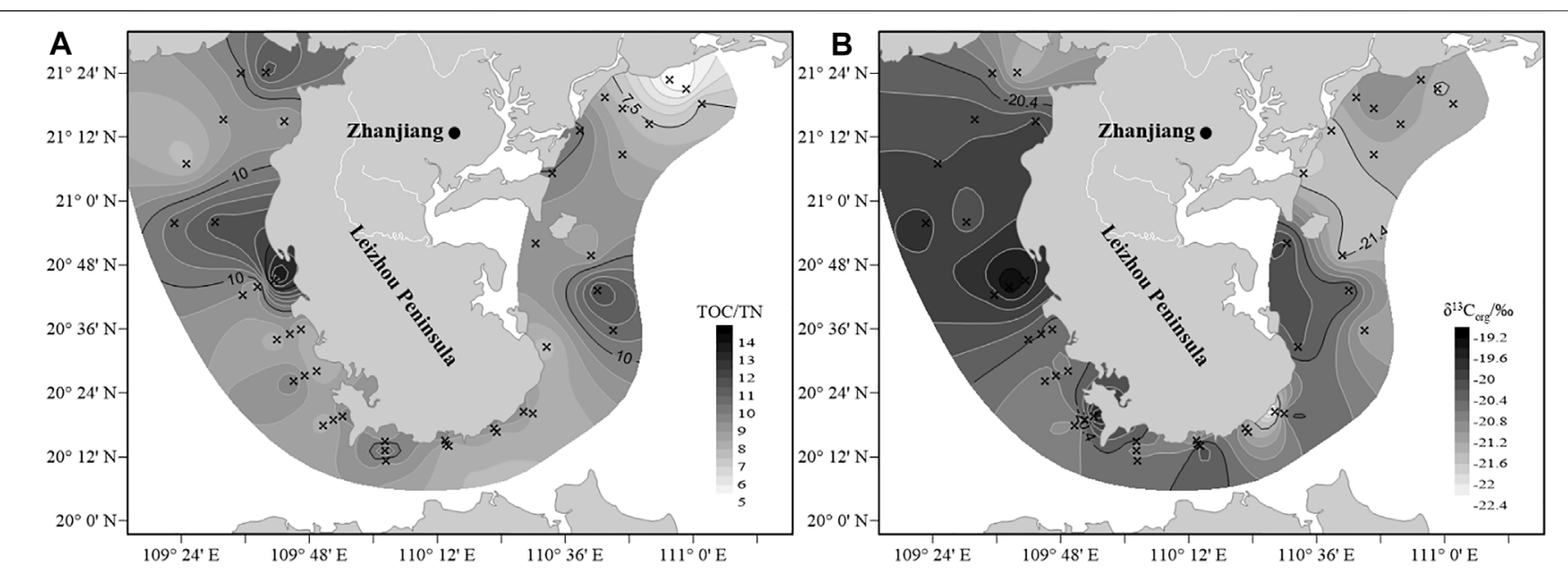

FIGURE 4 | Distribution of TOC/TN ratio (A) and organic carbon isotope $\left(\delta^{13} \mathrm{C}_{\circ \mathrm{org}}\right)$

(B) in the near offshore seafloor sediments surrounding the Leizhou Peninsula.

which suggests that they are affected by terrestrial organic matter. Figure 4A shows the TOC/TN ratio distribution in the seafloor samples of the Leizhou Peninsula offshore. The samples with TOC/TN ratio $<8$ are only distributed in a small area at the northeast Leizhou Peninsula offshore. This area is characterized by mud sediments and higher organic carbon content. Due to the influence of Pearl River material input under the coastal current in western Guangdong (Cao et al., 2017; Huang et al., 2020), higher primary productivity could consequently result in a higher amount of organic matter deposition, while the muddy sediments would be favorable for better organic matter preservation. The samples with $\mathrm{TOC} / \mathrm{TN}$ ratio $>12$, which is dominated by terrestrial organic matter, are mainly distributed in the middle area of the westside offshore. This area is a major seawater pearl production base in China and a vital shellfish culture area in Guangdong Province. Therefore, the organic matter content of the seafloor sediments could be affected by aquaculture and intensified biological metabolic activities. Most parts of the Leizhou Peninsula offshore show a mixed sedimentary organic matter input as their TOC/TN ratios of samples are in the range of $8-12$. The TOC/TN ratio in the seafloor samples also reveals that terrestrial organic input may significantly impact the carbon deposition and cycling in the most near offshore area of the Leizhou Peninsula region. Because the coastal area of the Leizhou Peninsula is one of the main distribution areas of mangroves (Yang et al., 2017), it is assumed that the coastal mangrove ecosystem and agriculture activities could have a significant effect on the sedimentary organic matter composition in the Leizhou Peninsula offshore. However, there is a paucity of information regarding the contribution or effect of mangroves on sedimentary organic matter in the offshore sediments.

Organic carbon isotopic composition $\left(\delta^{13} \mathrm{C}_{\text {org }}\right)$ has been widely used to distinguish the organic matter of marine source inputs (Schubert and Calvert, 2001). For example, $C_{3}$ vascular plants are typically characterized by isotopic compositions that are relatively depleted in ${ }^{13} \mathrm{C}(-22 \%$ $~-33 \%$, with an average of -27\%o; Fry and Sherr, 1984; Ramaswamy et al., 2008), while $\mathrm{C}_{4}$ plants display significant more enriched ${ }^{13} \mathrm{C}$ value $(-9 \%$ - $16 \%$, with an average of $-13 \%$; Pancost and Boot, 2004). For the typical marine phytoplankton, it exhibits intermediate $\delta^{13} \mathrm{C}$ values (-18\%o -21\%o, Goni et al., 1998). The values of $\delta^{13} \mathrm{C}_{\text {org }}$ in the surface sediments from the coastal Leizhou Peninsula range from $-22.47 \%$ o to $-19.18 \%$, with an average of $-20.61 \pm 0.71 \%$ o (Figure 4B; Table 1), is similar to that of marine organic matter. The distribution features of $\delta^{13} \mathrm{C}_{\text {org }}$ suggest that the sedimentary organic matter from the coastal Leizhou Peninsula is primarily marine originated with limited terrestrial source input. In addition, the most depleted $\delta^{13} \mathrm{C}_{\text {org }}$ values of organic matter were observed at the northeast coast of the Leizhou Peninsula which could be attributed to a riverine input by the Jianjiang river (Figure 4B).

In order to assess the relative proportions of terrigenous and marine autogenous organic carbon in the sediment samples, a two end-member mixing model based on $\delta^{13} \mathrm{C}_{\text {org }}$ was employed to distinguish the relative proportion of terrigenous and marine organic carbon in these sediments (Calder and Parker, 1968; Chen et al., 2012). The proportion of terrigenous and marine sourced organic carbon (Ogrinc et al., 2005) was calculated using the following equations:

$$
\begin{gathered}
\delta^{13} \mathrm{C}_{\text {org }}=f_{\mathrm{T}} \times \delta^{13} \mathrm{C}_{\mathrm{T}}+f_{\mathrm{M}} \times \delta^{13} \mathrm{C}_{\mathrm{M}} \\
f_{\mathrm{T}}+f_{\mathrm{M}}=1
\end{gathered}
$$

where $f_{\mathrm{T}}$ and $f_{\mathrm{M}}$ represent the terrestrial and marine organic matter fractions in the samples; $\delta^{13} \mathrm{C}_{\mathrm{T}}$ and $\delta^{13} \mathrm{C}_{\mathrm{M}}$ are the carbon isotopic compositions of the terrestrial and marine end-members, respectively. Based on the previous study in the adjacent area Daya Bay, the end-member values of $\delta^{13} \mathrm{C}_{\mathrm{T}}$ and $\delta^{13} \mathrm{C}_{\mathrm{M}}$ were $-26 \%$ and $-19 \%$, respectively (Qu et al., 2018). The estimated proportion of the terrestrial and marine organic matter in the Leizhou Peninsula offshore sediment samples are displayed in Figure 5. The seafloor sediments are dominated by marine sourced organic matter, which accounts for $77 \pm 10 \%$ on average. Although the lowest proportion of marine organic matter is recorded at station 22, the sediments from the east offshore area of the Leizhou Peninsula has less marine-derived 


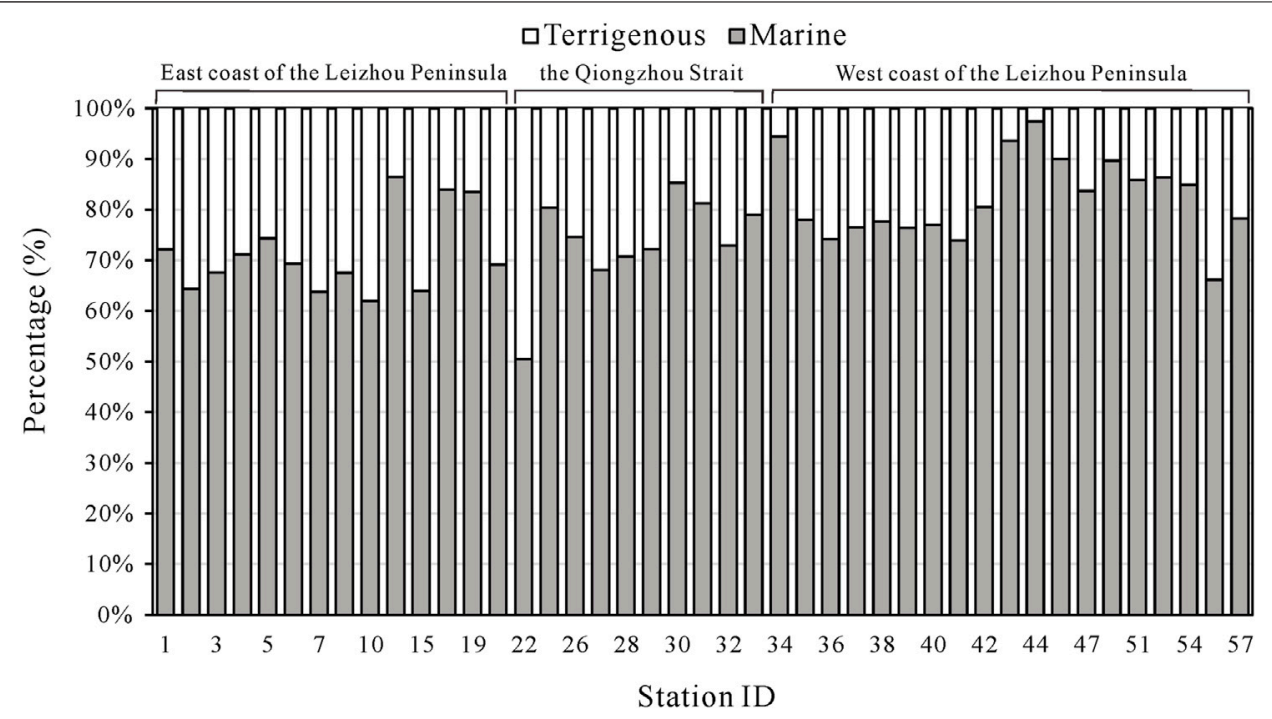

FIGURE 5 | The relative contribution of terrestrial and marine organic carbon in surface sediments.
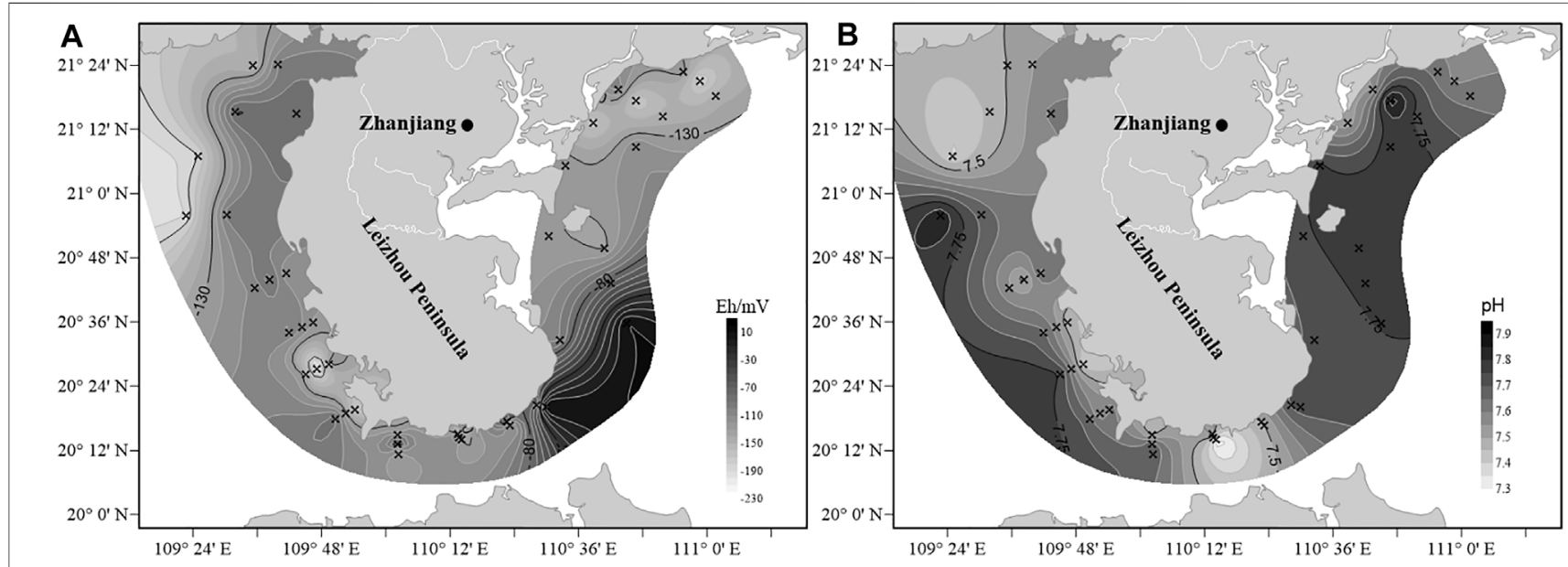

FIGURE 6 | Distributions of Eh (A) and pH (B) in the near offshore seafloor sediments surrounding the Leizhou Peninsula.

organic matter ( $71 \%$ on average) compared with that of the Qiongzhou Strait (75\% on average) and the west offshore area ( $82 \%$ on average). The composition of organic matter in sediments is the combination of multiple processes (primary production, hydrodynamics, preservation condition, source input, etc.) that determine organic carbon's biogeochemical cycle (Schubert and Calvert, 2001; Ogrinc et al., 2005).

\subsection{The Eh and pH Values of Sediments and Their Correlations With TOC}

The samples' $\mathrm{Eh}$ and $\mathrm{pH}$ values and their distribution are listed in Table 1 and shown in Figure 6. The Eh values of seafloor sediment samples surrounding the Leizhou Peninsula vary from -255.1 to $10.5 \mathrm{mv}$. According to the classification of redox potential and status of sediments proposed by Song Jinming and others, these sediments are in a weak reduction to reducing status (Song et al., 1990). Figure 6A shows that the higher Eh value areas generally coincide with the low organic carbon content areas. In contrast, the low Eh value areas are overlapped with the high organic carbon content areas. This is in agreement with that the Eh value of marine sediments is largely controlled by the abundance of organic matter (Wu et al., 2012). The various complex chemical and biochemical reactions occur in the seafloor sediments and would affect the geochemical behavior of various substances in the sediments, including the formation and transformation of authigenic minerals and the process of diagenesis (Zhu and Wang, 1980). The organic matter in the seafloor sediments is initially degraded by aerobic bacteria and fungi associated with the consumption of dissolved oxygen 

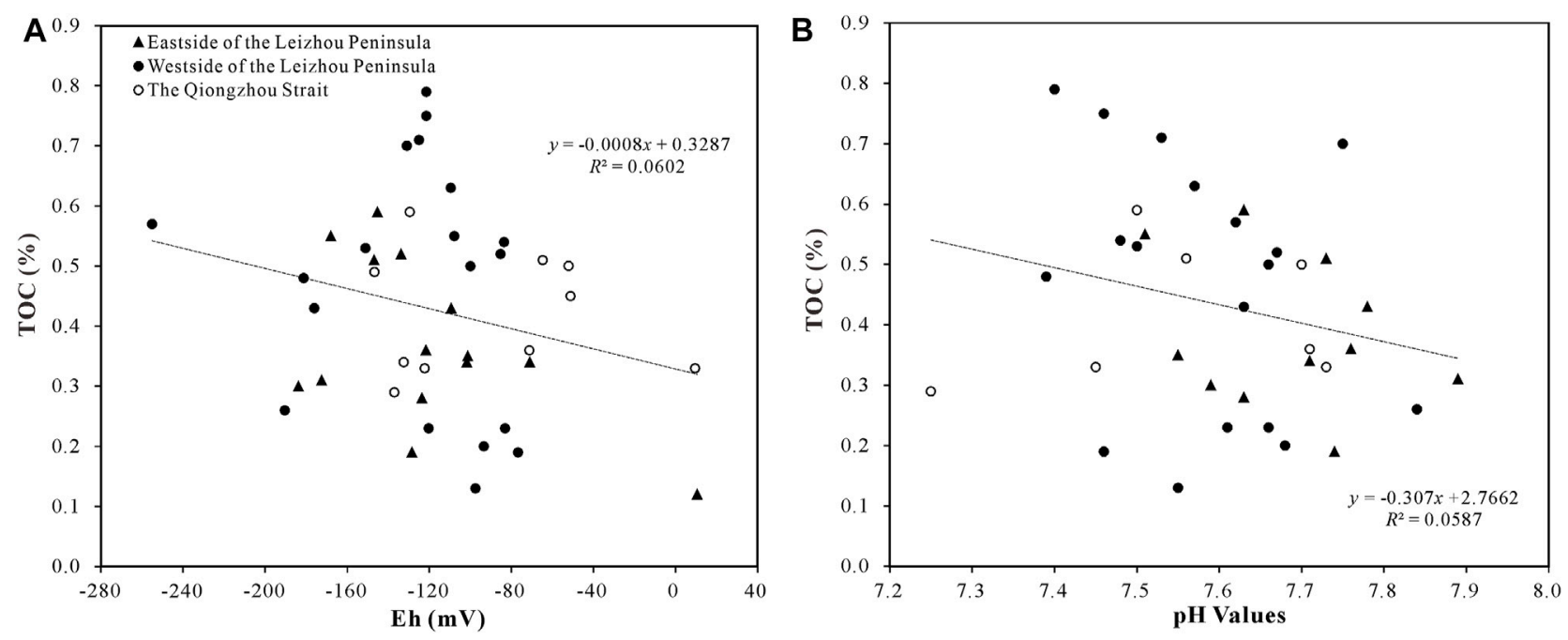

FIGURE 7 | Correlation between TOC and Eh potential (A), pH value (B) in the near offshore seafloor sediments surrounding the Leizhou Peninsula.

which leads to the decrease of Eh value in sediments (Wang et al., 2009; Feng et al., 2016). When oxygen is depleted, the organic matter would then be degraded by nitrate, manganese oxide, and sulfate-reducing bacteria, and associated with a continuous decrease of Eh value (Wu et al., 2012). In general, the high TOC content is often associated with strong activities of reducing bacteria, and the higher the TOC content, the lower the Eh value. Therefore, there is a negative correlation between TOC content and Eh value in the sediments. However, the TOC content displays a very weak correlation with Eh values with a coefficient of 0.0602 for the studied samples due to the narrow range of TOC distributions and similar Eh conditions. (Figure 7A). It has been proposed that the Eh value could be significantly influenced by the sulfur reduction when the Eh value is in the range of $-200 \sim 0 \mathrm{mV}$ (Vershinin and Rozanov, 1983; Song et al., 1990). On the other hand, the extraction of soluble organic matter in these seafloor samples shows that they contain a high abundance of elemental sulfur as the fresh copper sheets have been completed blacked during the solvent extraction (Jin et al., 2007; Rogowska et al., 2016). While the high content of elemental sulfur indicates strong evidence that the sulfate reduction process prevailed in these seafloor sediments. The free oxygen has been exhausted in the sediments due to the oxidation of organic matter and the oxidation reaction has turned to use the sulfate as oxidant. So, the oxidation of organic matter is related to the redox condition in the sediments. However, since the offshore sampling area is near the offshore region, the sedimentary environment could be complicated and influenced by various factors, weakening the negative correlation between TOC and Eh values.

The $\mathrm{pH}$ value of the Leizhou Peninsula offshore sediment samples ranges from 7.25 to 7.89 and indicates a weak alkaline depositional condition. Figure 6B shows that the $\mathrm{pH}$ value distribution in the offshore seafloor sediments displays a clear regional variation. The low $\mathrm{pH}$ values mainly occur in the near offshore areas of the Qiongzhou Strait, the northwest Beibu Gulf and near the coastal area of the Liusha Bay. The $\mathrm{pH}$ value of the offshore seafloor samples from the Beibu Gulf of the westside of the Leizhou Peninsula shows an increasing trend from the near coast to the far offshore area. The seafloor sediments in the eastside of the Leizhou Peninsula generally display a higher $\mathrm{pH}$ value of $>7.6$ with high value area located in the northeast offshore region. The $\mathrm{pH}$ value of the seafloor sediments is largely determined by the chemical property of the overlying seawater due to the interaction between the seafloor sediments and the bottom seawater (Qi et al., 2008). At the same time, carbonate and shellfish shells in the seafloor sediments would discharge carbonate ions, which would react with hydrogen ions in the bottom seawater, and could result in excessive hydroxide ions, which makes the seafloor water more alkaline, so the seafloor surface sediments are in a weakly alkaline status (Krumins et al., 2013). Figure 7B shows a weak negative correlation between TOC content and $\mathrm{pH}$ values with a coefficient of 0.0587, which suggests that the $\mathrm{pH}$ value of seafloor sediments has little influence on the abundance of sedimentary organic matter.

\subsection{Effects of Sedimentary Grain Size}

The seafloor samples are mainly composed of silt, clay and sand with a content of $14.6-66.6 \%$ (averaged at $53.6 \%$ ) for silt, a range of $9.4-39.6 \%$ (averaged at $27.9 \%$ ) for clay and a range of $3.4-76.1 \%$ for sand. The granularity of sediments is an important factor in controlling the abundance of organic matter in the seafloor sediments as it reflects the seafloor hydrodynamic conditions. According to the correlation between the TOC content and the contents of clay, silt and sand (Figure 8), the TOC content shows a slightly positive correlation with the clay, silt and mean size with a Pearson correlations coefficient $(r)$ of $0.593,0.617$ and $0.548(p<0.01)$, respectively. But a clear negative correlation with the sand content $(\mathrm{r}=-0.684, p<0.01$; Figure $8 \mathrm{C})$. The clay content of the seafloor samples from the west side of the Leizhou Peninsula 

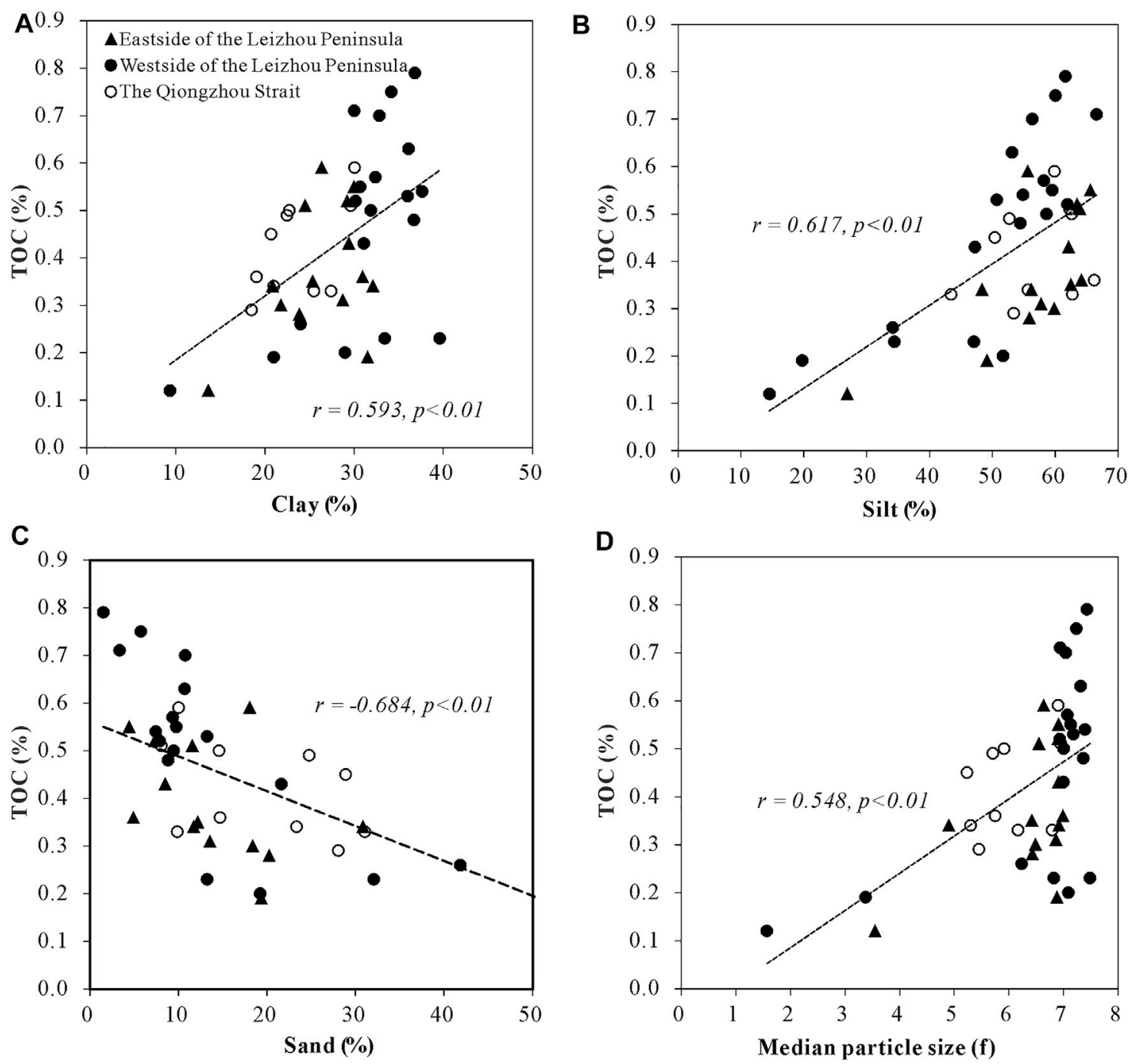

FIGURE 8 | Correlations between TOC content and Clay (A), Silt (B), Sand (C), Median particle size (D) in the near offshore seafloor sediments surrounding the Leizhou Peninsula.

is generally higher than that of the samples from the eastern side of the Leizhou Peninsula and the Qiongzhou Strait. Figure 9 shows the distribution of clay content in the seafloor samples of the near offshore region surrounding the Leizhou Peninsula. This contour plot of the clay content shows that the high content area overlaps with the high TOC content area in the seafloor sediments surrounding the Leizhou Peninsula. The northeastern offshore area of the Beibu Gulf is a low TOC content area and this is related to the high content of sand in the seafloor sediments as the coastal area experienced strong tide erosion (Xia et al., 2001; Xu et al., 2012). The seafloor of the Qiongzhou Strait is a strong eroded area, where the strong currents are not favorable for the fine particle deposits and the organic matter preservation due to the high oxygen content of seawater (Shi and Chen, 1998; Chen et al., 2015). Consequently, the TOC contents in these high hydrodynamic seafloor sediments are often lower and this is common in shallow offshore areas of

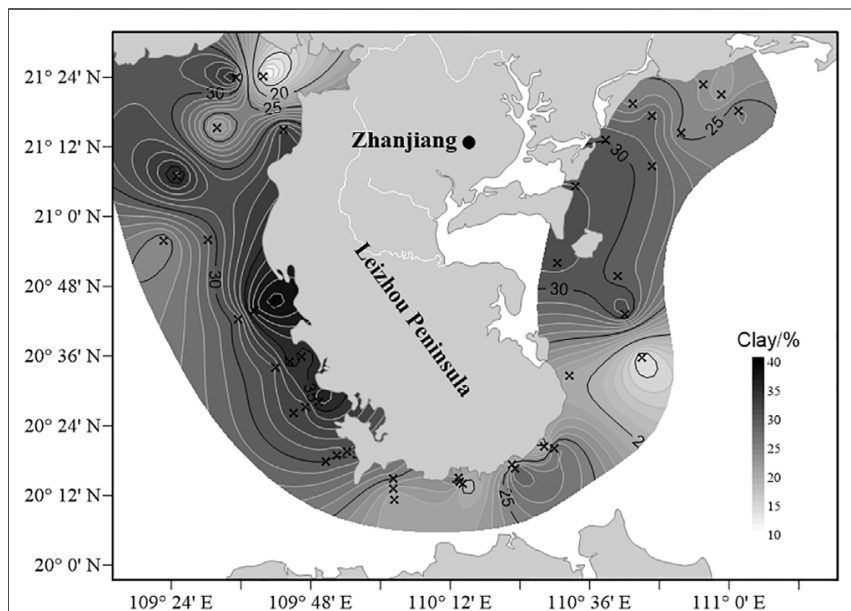

FIGURE 9 | The distribution of clay content in the near offshore seafloor sediments surrounding the Leizhou Peninsula. 
Bohai, the Yellow Sea and the Yangtze River estuary (Hu et al., 2013; Yao et al., 2014; Gao et al., 2016).

\section{CONCLUSION}

The investigation of the TOC, TN contents, organic carbon isotopic composition and their distributions in the offshore seafloor sediment samples surrounding the Leizhou Peninsula could be concluded into following points: 1) both TOC and TN contents in these seafloor sediment samples is significantly lower compared with that of seafloor sediments from other offshore areas of China. The low TOC and TN contents and a lack of benthic organisms observed in the sediment could be suggestive of a desertification status or trend in the offshore seafloor region surrounding the Leizhou Peninsula; 2) The organic carbon isotopic composition and TOC/TN ratio suggest that the sedimentary organic matter is mixed sourced from both terrestrial input and marine input but dominated by the marine sourced organic matter. 3) The seafloor sediments from the offshore region surrounding the Leizhou Peninsula are generally in a weak reduction to reduction status. A weak negative linear correlation between the TOC contents and Eh values suggests that the redox potential of sediments is largely controlled by the abundance of organic matter. On the other hand, $\mathrm{pH}$ values seem to have no effect on the TOC content and its distribution in these offshore seafloor sediments surrounding the Leizhou Peninsula; 4) The positive correlation between TOC and clay, silt content, and median particle size $(\Phi)$ of the sediments

\section{REFERENCES}

Berner, R. A., Beerling, D. J., Dudley, R., Robinson, J. M., and Wildman, R. A., Jr (2003). Phanerozoic Atmospheric Oxygen. Annu. Rev. Earth Planet. Sci. 31 (1), 105-134. doi:10.1146/annurev.earth.31.100901.141329

Bianchi, T. S., and Allison, M. A. (2009). Large-river delta-front Estuaries as Natural "recorders" of Global Environmental Change. Proc. Natl. Acad. Sci. 106 (20), 8085-8092. doi:10.1073/pnas.0812878106

Bianchi, T. S., Cui, X., Blair, N. E., Burdige, D. J., Eglinton, T. I., and Galy, V. (2018). Centers of Organic Carbon Burial and Oxidation at the Land-Ocean Interface. Org. Geochem. 115, 138-155. doi:10.1016/j.orggeochem.2017.09.008

Blair, N. E., and Aller, R. C. (2012). The Fate of Terrestrial Organic Carbon in the Marine Environment. Annu. Rev. Mar. Sci. 4 (1), 401-423. doi:10.1146/ annurev-marine-120709-142717

Borges, A. V., Delille, B., and Frankignoulle, M. (2005). Budgeting Sinks and Sources of $\mathrm{CO}_{2}$ in the Coastal Ocean: Diversity of Ecosystems Counts. Geophys. Res. Lett. 32 (14), L14601. doi:10.1029/2005gl023053

Burdige, D. J. (2005). Burial of Terrestrial Organic Matter in marine Sediments: A Re-assessment. Glob. Biogeochem. Cycles 19 (4). doi:10.1029/2004GB002368

Burdige, D. J. (2007). Preservation of Organic Matter in marine Sediments: Controls, Mechanisms, and an Imbalance in Sediment Organic Carbon Budgets? Chem. Rev. 107, 467-485. doi:10.1021/cr050347q

Cai, D., Sun, Y., Zhang, X., Su, Y., Wu, Y., Chen, Z., et al. (2014). Reconstructing a Primary Productivity History Over the Past 200a Using Sediment Organic Carbon Content and the Stable Isotope Composition in the East China Sea and the Yellow Sea. Acta Oceanologica Sinica 36 (2), 40-50. doi:10.3969/j.issn.0253-4193.2014.02.005

Calder, J. A., and Parker, P. L. (1968). Stable Carbon Isotope Ratios as Indexes of Petrochemical Pollution of Aquatic Systems. Environ. Sci. Technol. 2, 535-539. doi:10.1021/es60019a001 indicates that the clay and silt sedimentary condition is favorable for the organic matter preservation.

\section{DATA AVAILABILITY STATEMENT}

The original contributions presented in the study are included in the article/supplementary material, further inquiries can be directed to the corresponding author.

\section{AUTHOR CONTRIBUTIONS}

$\mathrm{XJ}$ and SZ contributed to conception of the study. Samples were collected by XJ, HY, and TJ. XJ, HY, and AA performed the experimental analysis. XJ wrote the first draft of the manuscript. $\mathrm{SZ}$ revised the manuscript.

\section{FUNDING}

This study was funded by the Special Talent Support Program of Guangdong Ocean University (No. R17001), the Project of Enhancing School with Innovation of Guangdong Ocean University (GDOUQ18301), the First-class special Funds of Guangdong Ocean University (231419029), the Project of Marine geochemistry and climate change of Guangdong Ocean University (No. 002026002004) and the Fund of Southern Marine Science and Engineering Guangdong Laboratory (Zhanjiang) (Grant No. ZJW2019-08).

Cao, M., Ma, Q., Wu, Y., and Zhang, J. (2017). Difference in Organic Matter Distribution and Degradation in Surface Sediment between Northern South China Sea and Hainan Island. Oceanologia et Limnologia Sinica 48 (2), 258-265. doi:10.11693/hyhz20160900188

Chen, B., and Shi, M. (2019). Advances in Study of Beibu Gulf Circulation. Guangxi Sci. 26 (06), 595-603. doi:10.13656/j.cnki.gxkx.20200103.001

Chen, F. J., Chen, J., Jin, H., Li, H., Zheng, L., and Zhang, H. (2012). Correlation of $\delta^{13} \mathrm{C}_{\text {org }}$ in Surface Sediments with Sinking Particulate Matter in South China Sea and Implication for Reconstructing Paleo-Environment. Acta Sedimentologica Sinica 30 (2), 340-345. doi:10.14027/j.cnki.cjxb.2012.02.013

Chen, L., Yan, J., and Ma, D. (2015). Comprehensive Analysis of Hydrodynamic Characteristics Simulation of Haikou Port Construction Plan of Qiongzhou Strait Automobile Ferry. China Water Transport (the second half of the month) 15 (09), 273-275.

Chen, L., Zhang, Y., Li, T., Yang, W., and Chen, J. (2014). Sedimentary Environment in the Qiongzhou Strait and its Surrounding Waters and Sedimentary Evolution in the Past 10,000 Years. Earth Sci. (Journal China Univ. Geosciences) 39 (06), 696-704. doi:10.3799/dqkx.2014.065

Chen, Z. Z., Qiu, Y. S., Jia, X. P., and Zhong, Z. H. (2008). Effects of Fishing on the marine Ecosystem of Beibu Gulf. Ying Yong Sheng Tai Xue Bao 19 (07), 1604-1610. doi:10.13287/j.1001-9332.2008.0292

Cui, Z., Lin, J., Gan, H., Liu, W., and Zhang, L. (2015). Geochemical Characteristics of Surface Sediments in the Eastern Waters of the Beibu Gulf of the South China Sea. Mar. Sci. 39 (07), 103-111.

Cui, Z., Xia, Z., Lin, J., and Shi, Y. (2017). Holocene Environmental Evolution and Anthropogenic Impact of Beibu Gulf, South China Sea. Beijing, China: Ocean Press, 189-191.

EBCBS (1993). Survey of China Bays, 12. Beijing: Ocean Press, 73.

Falkowski, P., Scholes, R. J., Boyle, E., Canadell, J., Canfield, D., Elser, J., et al. (2000). The Global Carbon Cycle: a Test of Our Knowledge of Earth as a 
System: A Test of Our Knowledge of Earth as a System. Science 290 (5490), 291-296. doi:10.1126/science.290.5490.291

Fan, X., Cheng, F., Yu, Z., and Song, X. (2017). The Distribution Characteristics of Sediment Particle Size and Biogenic Factors in the Yangtze Estuary and its Adjacent Waters. Mar. Sci. 41 (07), 105-112. doi:10.11759/hykx20170109001

Feng, W., Wang, Z., Zhang, R., Zhang, D., Ye, M., Chen, D., et al. (2016). The Environment Characteristics of Redox in the Surface Sediments of Ningde Coastal Sea Area in Relation to Influence Factors. Mar. Environ. Sci. 35 (6), 882-887. doi:10.13634/j.cnki.mes.2016.06.013

Folk, R. L., Andrews, P. B., and Lewis, D. W. (1970). Detrital Sedimentary Rock Classification and Nomenclature for Use in New Zealand. New Zealand J. Geology. Geophys. 13 (4), 937-968. doi:10.1080/00288306.1970.10418211

Fry, B., and Sherr, E. B. (1984). $\delta^{13} \mathrm{C}$ Measurements as Indicators of Carbon Flow in marine and Fresh-Water Ecosystems. Contrib. Mar. Sci. 27, 13-14.

Gao, L., Yao, P., Wang, J., and Zhao, B. (2016). Distribution and Sources of Organic Carbon in Surface Sediments from the Bohai Sea. Acta Oceanologica Sinica 38 (6), 8-20. doi:10.3969/j.issn.0253-4193.2016.06.002

Gao, X., Song, J., Li, X., Long, A., and Chen, S. (2008). Analysis on the Main Progress and Key Influencing Factors of China's Offshore Carbon Cycle Research. Mar. Sci. 32 (3), 83-90.

Goni, M. A., Ruttenberg, K. C., and Eglinton, T. I. (1998). A Reassessment of the Sources and Importance of Land-Derived Organic Matter in Surface Sediments from the Gulf of Mexico. Geochimica Et Cosmochimica Acta 62 (18), 3055-3075. doi:10.1016/s0016-7037(98)00217-8

Goslin, J., Sansjofre, P., Van Vliet-Lanoe, B. V., and Denmark, C. (2017). Carbon Stable Isotope and Elemental (TOC, TN)geochemistry in Salymarsh Surface sediments(Western Brittany, France): a Useful Tool for reconstructingHolocene Relative Sea-Level. J. Quat. Sci. 32 (7), 987-1007. doi:10.1002/jqs.2971

Graf, G., and Rosenberg, R. (1997). Bioresuspension and Biodeposition: a Review. J. Mar. Syst. 11 (3-4), 269-278. doi:10.1016/s0924-7963(96)00126-1

Gu, Y., Wang, C., Lü, S., Yang, Y., Feng, J., Fang, J., et al. (2010). Distribution and Pollution Assessment of Biogenic Sediments in Surface Sediments in Western Guangdong. J. Shenzhen Univ. (science technology) 27 (03), 347-353. doi:10.3969/j.issn.1000-2618.2010.03.018

Guo, Z., Yang, Z., Chen, Z., and Deng, Mao. (2001). Provenance Analysis of Sedimentary Organic Matter in the Mud Area of the East China Sea Continental Shelf. Geochemistry 30 (5), 416-424. doi:10.19700/j.0379-1726.2001.05.002

Hu, L., Shi, X., Guo, Z., Wang, H., and Yang, Z. (2013). Sources, Dispersal and Preservation of Sedimentary Organic Matter in the Yellow Sea: The Importance of Depositional Hydrodynamic Forcing. Mar. Geology. 335 (1), 52-63. doi:10.1016/j.margeo.2012.10.008

Huang, C., Chen, F., Zhang, S., Chen, C., Meng, Y., Zhu, Q., et al. (2020). Carbon and Nitrogen Isotopic Composition of Particulate Organic Matter in the Pearl River Estuary and the Adjacent Shelf. Estuarine, Coastal Shelf Sci. 246, 107003. doi:10.1016/j.ecss.2020.107003

Jin, H., Wan, S., Zhang, J., Song, Z., Zhao, D., Huang, J., et al. (2019). Distribution Characteristics and Provenance of Surface Clay Minerals in Beibu Gulf. Mar. Sci. 43 (01), 75-84. doi:10.11759/hykx20180423001

Jin, M., Xia, Y., Lei, T., Ma, S., Qiu, J., and Zhang, R. (2007). Note on Sulfur Removal with Metallic Copper. Geochem. Int. 45 (6), 620-623. doi:10.1134/ s0016702907060109

Kang, Z., Yu, R., Kong, F., Gao Yan, W. Y., Guo, Wei., Chen, J., et al. (2014). Composition, Content and Distribution of Pigment in spring Surface Sediments in Red Tide Area South of Changjiang Estuary. Mar. Sci. 38 (10), 30-39. doi:10.11759/hykx20130423001

Krumins, V., Gehlen, M., Arndt, S., Van Cappellen, P., and Regnier, P. (2013). Dissolved Inorganic Carbon and Alkalinity Fluxes from Coastal marine Sediments: Model Estimates for Different Shelf Environments and Sensitivity to Global Change. Biogeosciences 10 (1), 371-398. doi:10.5194/bg10-371-2013

Larowe, D. E., Arndt, S., Bradley, J. A., Estes, E. R., Hoarfrost, A., Lang, S. Q., et al. (2020). The Fate of Organic Carbon in marine Sediments - New Insights from Recent Data and Analysis. Earth-Science Rev. 204, 103146. doi:10.1016/ j.earscirev.2020.103146

Lian, Z., Jiang, Z., Huang, X., Zhang, L., Wu, Y., and Liu, S. (2019). Spatial Distribution Characteristics of Different Extracts of Organic Carbon in Surface
Sediments from the Pearl River Estuary. Mar. Environ. Sci. 38 (3), 391-398. doi:10.13634/j.cnki.mes.2019.03.011

Liu, D., and Chao, Q. (2019). Study on the Spatial and Temporal Distribution Oc Chlorophyll a Concentration in Beibu Gulf. J. Mar. Sci. 37 (2), 95-102. doi:10.3969/j.issn.1001-909X.2019.02.010

Liu, D., Li, X., Emeis, K.-C., Wang, Y., and Richard, P. (2015). Distribution and Sources of Organic Matter in Surface Sediments of Bohai Sea Near the Yellow River Estuary, China. Estuarine, Coastal Shelf Sci. 165 (NOV.5), 128-136. doi:10.1016/j.ecss.2015.09.007

Liu, F., Yang, C., Chang, X., and Liao, Z. (2018). Provenance Discrimination of the Last Glacial Sediments from the Northeastern South China Sea and its Paleoenvironmental Indications. Terr. Atmos. Ocean. Sci. 29 (2), 131-148. doi:10.3319/tao.2017.07.31.01

Liu, W., Wang, R., and Li, C. (1998). Carbon to Nitrogen Ratio in the East China Sea Particulate Organic Matter. Oceanologia Et Limnologia Sinica 29 (5), $467-470$.

Liu, X., Tang, D., and Ge, C. (2020). Distribution and Sources of Organic Carbon, Nitrogen and Their Isotopic Composition in Surface Sediments from the Southern Yellow Sea, China. Mar. Pollut. Bull. 150, 110716. doi:10.1016/ j.marpolbul.2019.110716

Luo, Z., Zhu, C., Guo, Y., Su, L., Li, J., and Ou, Y. (2013). Distribution Characteristics of C, N and P in Liusha Bay Surface Sediments and Their Pollution Assessment. South China Fish. Sci. 10 (3), 1-8. doi:10.3969/ j.issn.2095-0780.2014.03.001

Ma, R., He, Y., Yang, Y., Xia, N., Guo, Y., Zhang, G., et al. (2012). Geochemical Characteristic of Surface Sediments from the Qiongzhou Strait. Mar. Sci. Bull. 31 (2), 131-135. doi:10.11840/j.issn.1001-6392.2012.2.002

Muschenheim, D. K. (1987). The Dynamics of Near-Bed Seston Flux and Suspension-Feeding Benthos. J. Mar. Res. 45 (2), 473-496. doi:10.1357/ 002224087788401098

Ogrinc, N., Fontolan, G., Faganeli, J., and Covelli, S. (2005). Carbon and Nitrogen Isotope Compositions of Organic Matter in Coastal marine Sediments (The Gulf of Trieste, N Adriatic Sea): Indicators of Sources and Preservation. Mar. Chem. 95 (3-4), 163-181. doi:10.1016/j.marchem.2004.09.003

Pancost, R. D., and Boot, C. S. (2004). The Palaeoclimatic Utility of Terrestrial Biomarkers in marine Sediments. Mar. Chem. 92, 239e261. doi:10.1016/ j.marchem.2004.06.029

Qi, H. (2008). pH and Eh Distribution and Constraints of Surface Sediments in the Changjiang Estuary and Adjacent Waters. Acta Sedimentologica Sinica 26 (5), 820-827. doi:10.14027/j.cnki.cjxb.2008.05.022

Qu, B. X., Song, J. M., and Yuan, M. H. (2018). Sediment Records and Responses for Anthropogenic Activities of Organic Matter in the Daya Bay during Recent One Hundred Years. Haiyang Xuebao 40 (10), 119-130. doi:10.3969/ j.issn.0253-4193.2018.10.012

Ramaswamy, V., Birgit, G., Shirodkar, P. V., Rao, P. S., Chivas, A. R., Wheeler, D., et al. (2008). Distribution and Sources of Organic Carbon, Nitrogen and Their Isotopic Signatures in Sediments from the Ayeyarwady (Irrawaddy) continental Shelf, Northern Andaman Sea. Mar. Chem. 111 (3-4), 137-150. doi:10.1016/ j.marchem.2008.04.006

Rogowska, J., Sychowska, J., Cieszynska-Semenowicz, M., and Wolska, L. (2016). Elemental Sulfur in Sediments: Analytical Problems. Environ. Sci. Pollut. Res. 23 (24), 24871-24879. doi:10.1007/s11356-016-7739-1

Schubert, C. J., and Calvert, S. E. (2001). Nitrogen and Carbon Isotopic Composition of Marine and Terrestrial Organic Matter in Arctic Ocean Sediments: Nitrogen and Carbon Isotopic Composition of Marine and Terrestrial Organic Matter in Arctic Ocean Sediments:: Implications for Nutrient Utilization and Organic Matter Composition. Deep Sea Res. Oceanographic Res. Pap. 48 (3), 789-810. doi:10.1016/S0967-0637(00)00069-8

Shi, M., and Chen, C. (1998). Characteristics of the Tidal Residual Flow Field in the Late winter and Early spring of Qiongzhou Strait. Acta Sedimentologica Sinica 20 (1), 1-10.

Song, J., Li, Y., and Zhu, Z. (1990). Relationship between Eh and Redox Environment of marine Sediments. Mar. Sci. Bull. 9 (4), 33-39.

Thompson, J. D. (1978). Ocean Deserts and Ocean Oases. Climatic Change 1 (3), 205-230. doi:10.1007/bf00166175

Vershinin, A. V., and Rozanov, A. G. (1983). The Platinum Electrode as an Indicator of Redox Environment in marine Sediments. Mar. Chem. 14 (1), 1-15. doi:10.1016/0304-4203(83)90065-8 
Wang, J., Qi, H., Li, N., and Tan, L. (2009). The Sediment Redox Environment of the Shandong Coast. Periodical Ocean Univ. China 39 (Sup), 184-188. doi:10.16441/j.cnki.hdxb.2009.s1.035

Wang, X., Yu, J., and Fan, H. (2020). Spatial and Seasonal Variability of Surface Particulate Inorganic Carbon and Relationship with Particulate Organic Carbon in the Yellow-Bohai Sea. J. Oceanogr 76 (5), 327-339. doi:10.1007/ s10872-020-00547-5

Wang, Y., and Yuan, W. (2008). Changes of Demersal Trawl Fishery Resources in Northern South China Sea as Revealed by Demersal Trawling. South China Fish. Sci. 4 (2), 26-33. doi:10.3969/j.issn.2095-0780.2008.02.005

Wu, J., Liu, G., Wang, N., Xu, X., and Song, L. (2012). Oxidation-reduction Potential of Surface Sediments in the Northern Part of Liaodong Bay and its Main Influencing Factors. Acta Sedimentologica Sinica 30 (2), 333-339. doi:10.14027/j.cnki.cjxb.2012.02.012

Wu, Y. (2008). The Temporal and Spatial Patterns and Size-Fractioned Structure of Primary Productivity in Beibu Gulf. Xiamen: Xiamen University.

Xia, H., Li, S., and Shi, M. (2001). Three-dimensional Wind Flow and Density Flow Simulation in Beibu Gulf. Acta Oceanologica Sinica 23 (06), 11-23. doi:10.3321/ j.issn:0253-4193.2001.06.002

Xiong, L., Shi, X., Deng, Y., and Bai, Y. (2013). Distribution Characteristics of the Organic Matter in the Surficial Sediments on the Shelf of the Southern Yellow Sea and the Northern East China Sea. Mar. Sci. Bull. 32 (3), 281-286. doi:10.11840/j.issn.1001-6392.2013.03.007

Xu, D., Chu, F., Yang, H., Chen, L., and Li, T. (2012). Modern Deposition Rate in the Beibu Gulf. Mar. Geology. Quat. Geology. 32 (6), 17-26. doi:10.3724/ sp.j.1140.2012.02127

Yang, J., Jay, G., Liu, B., and Alan, C. (2012). Mangrove Edge Effect in Leizhou Peninsula and its Impact on Coastal Organic Carbon Pool. Acta Oceanologica Sinica 34 (5), 161-168. doi:10.3724/sp.j.1095.2012.00134

Yang, Q., Qu, K., Yang, S., Sun, Y., Zhang, Y., and Zhou, M. (2021). Environmental Factors Affecting Regional Differences and Decadal Variations in the Buried Flux of marine Organic Carbon in Eastern Shelf Sea Areas of China. Acta Oceanol. Sin. 40 (6), 26-34. doi:10.1007/s13131-020-1601-5

Yang, S., Bao, X., Chen, C., and Chen, F. (2003). Characteristics of the Coastal Stream in Western Guangdong in Summer and its Production Mechanism. Acta Oceanologica Sinica 25 (06), 1-8. doi:10.3321/j.issn:02534193.2003.06.001

Yang, S., Lu, W., Zou, Z., and Li, S. (2017). Mangrove Wetlands: Distribution, Species Composition and Protection in China. Subtropical Plant Sci. 46 (4), 301-310. doi:10.3969/j.issn.1009-7791.2017.04.001

Yao, H., Gong, Z., Zhong, W., Na, Z., and Wei, Y. (2021). A Study on the Correlation Between Primary Productivity and Environmental Factors in Guangxi Beibu Gulf. Mar. Environ. Sci. 40 (2), 242-249. doi:10.13634/ j.cnki.mes.2021.02.012

Yao, P., Zhao, B., Bianchi, T. S., Guo, Z., Zhao, M., Li, D., et al. (2014). Remineralization of Sedimentary Organic Carbon in Mud Deposits of the Changjiang Estuary and Adjacent Shelf: Implications for Carbon Preservation and Authigenic mineral Formation. Continental Shelf Res. 91, 1-11. doi:10.1016/j.csr.2014.08.010

Ye, X., Chen, J., Wang, A., Huang, C., Wang, W., and Li, D. (2011). Sources and Burial of Carbon in Sediments from the Western Taiwan Strait. Acta Oceanologica Sinica 33 (05), 73-82.

Yu, M., Eglinton, T. I., Haghipour, N., Montluçon, D. B., Wacker, L., Hou, P., et al. (2021). Contrasting Fates of Terrestrial Organic Carbon Pools in Marginal Sea Sediments. Geochimica et Cosmochimica Acta 309, 16-30. doi:10.1016/ j.gca.2021.06.018

Yuan, X., Yang, Q., Luo, X., Yu, F., Liu, F., Li, J., et al. (2019). Distribution of Grain Size and Organic Elemental Composition of the Surficial Sediments in Lingding Bay in the Pearl River Delta, China: A Record of Recent Human Activity. Ocean Coastal Manage. 178, 104849. doi:10.1016/j.ocecoaman.2019.104849

Yue, D., Wang, L., and Zhu, X. (2017). Problems and Countermeasures in the Supply Side of marine Capture Fishery in China. J. Agric. Sci. Tech. 19 (7), 17-26. doi:10.13304/j.nykjdb.2016.687

Zhang, C., Lin, H., and Sun, X. (2012). Sources and Distribution of Sedimentary Organic Matter in Typical Bays of Guangdong Province. J. Trop. Oceanography 31 (06), 62-68. doi:10.3969/j.issn.1009-5470.2012.06.010

Zhang, J., Xie, Q., Shi, Y., Li, X., and Sun, X. (2011). Redox Characteristics of Surface Sediments in Zhanjiang Harbor and its Influencing Factors. Mar. Environ. Sci. 30 (06), 823-826. doi:10.3969/j.issn.1007-6336.2011.06.014

Zhang, S., Liang, C., and Xian, W. (2020). Spatial and Temporal Distributions of Terrestrial and marine Organic Matter in the Surface Sediments of the Yangtze River Estuary. Continental Shelf Res. 203, 104158. doi:10.1016/j.csr.2020.104158

Zhang, T., Li, X., Lan, H., Sun, S., and Jiang, Z. (2014). Distribution Characteristics and Influencing Factors of Lignin in Surface Sediments of the Yellow Sea. Mar. Environ. Sci. 33 (06), 822-829. doi:10.13634/j.cnki.mes.2014.06.002

Zhu, E., and Wang, Q. (1980). Marine Authigenic mineral. Beijing: Ocean Press, 12-17.

Conflict of Interest: The authors declare that the research was conducted in the absence of any commercial or financial relationships that could be construed as a potential conflict of interest.

Publisher's Note: All claims expressed in this article are solely those of the authors and do not necessarily represent those of their affiliated organizations, or those of the publisher, the editors and the reviewers. Any product that may be evaluated in this article, or claim that may be made by its manufacturer, is not guaranteed or endorsed by the publisher.

Copyright (C) 2022 Xia, Han, Tan, Abarike and Song. This is an open-access article distributed under the terms of the Creative Commons Attribution License (CC BY). The use, distribution or reproduction in other forums is permitted, provided the original author(s) and the copyright owner(s) are credited and that the original publication in this journal is cited, in accordance with accepted academic practice. No use, distribution or reproduction is permitted which does not comply with these terms. 